\title{
Adaptation to cold and predation-shelter use by invasive raccoon dogs Nyctereutes procyonoides in Białowieża Primeval Forest (Poland)
}

\author{
Rafał Kowalczyk • Andrzej Zalewski
}

Received: 23 November 2009/Revised: 14 May 2010 /Accepted: 23 May 2010 /Published online: 8 June 2010

(C) The Author(s) 2010. This article is published with open access at Springerlink.com

\begin{abstract}
Based on radio-tracking of raccoon dogs Nyctereutes procyonoides in Białowieża Primeval Forest (E Poland) in 1997-2002, we addressed the hypothesis that pattern of shelter use by this invasive carnivore is an adaptation to both climatic conditions and predation. Raccoon dogs used various types of shelters but were invariably concealed in dense vegetation or in the shelters created by trunks, branches, or roots of fallen trees $(58 \%$ of days). Burrows (mainly badger setts) and hollow trees (mainly fallen limes) were selected on $27 \%$ and $14 \%$ of days, respectively. The pattern of shelter use varied throughout the year. In crucial periods (breeding period and winter), raccoon dogs used shelter offering better protection: burrows and hollow trees (use of which increased with decreasing ambient temperature) in winter, and hollow trees and dense vegetation during breeding and raising pups. The pattern of shelter use by raccoon dogs was also strongly modified by forest structure. Raccoon dogs living in the pristine old-growth stands (with large amounts of dead wood) utilized mainly natural shelters created by fallen trees (trunks, branches, and roots) and sedge tussocks (38\% and $37 \%$, respectively). Individuals inhabiting the managed part of the Forest used mainly burrows $(43 \%)$ and thicket $(23 \%)$. We recorded very strong monogamous relationships between pair mates, manifested by shared resting on $84 \%$ of days per year. We conclude that hiding behavior and plasticity in shelter use is a response to high mortality due to predation and to unfavorable climatic conditions. High adaptability to
\end{abstract}

Communicated by C. Gortázar.

R. Kowalczyk $(\bowtie) \cdot$ A. Zalewski

Mammal Research Institute, Polish Academy of Sciences,

17-230 Białowieża, Poland

e-mail: rkowal@zbs.bialowieza.pl various environmental conditions may be one of the factors underlying successful range expansion of raccoon dogs in Europe.

Keywords Raccoon dog P Predation avoidance - Den use · Climatic conditions $\cdot$ Badger sett $\cdot$ Hollow lime tree

\section{Introduction}

Safe shelters are, for many species of animals, crucial for their survival and reproduction (Reichman and Smith 1990). They provide refuge against predators and protection against harsh climatic conditions (Buskirk 1984; Zalewski 1997a). Their characteristics, use, and distribution have been the subject of numerous studies (e.g., Magoun and Copeland 1998; Kowalczyk et al. 2000, 2004; Zalewski 1997b; Cantú-Salazar et al. 2009; Herr et al. 2010).

The use of shelters for many species of carnivores is an essential part of their life strategy; however, they differ in the extent and reasons for den-site use. Often animals rest in provisional lairs, and they select for cover, rather than specific shelter (Podgórski et al. 2008). Safer den sites (burrows, tree holes, and cavities) are used usually in critical periods of the annual life cycle, such as reproduction or wintering (Fernandez and Palomares 2000; McLoughlin et al. 2002). Some species of carnivores, such as wolves (Canis lupus) or red foxes (Vulpes vulpes) utilize dens mainly for the protection of their infant young (Jędrzejewski et al. 2001; Theuerkauf et al. 2003; Goszczyński et al. 2008). For others, such as pine martens (Martes martes) shelters are an immediate refuge from extreme climatic conditions (Zalewski 1997a). Badgers (Meles meles) and brown bears (Ursus arctos) 
spend the greater part of their annual life cycle in safe dens (usually burrows or hollow trees), using them for reproduction, winter hibernation, and resting sites during day-light (Friebe et al. 2001; Kowalczyk et al. 2003). The availability of shelters is influenced by habitat structure and this may influence the behavior of animals (Zalewski 1997b).

The raccoon dog Nyctereutes procyonoides is a mediumsized carnivore, which spread over eastern, central, and northern Europe after its introduction from eastern Asia to the European part of the former Soviet Union in 1920s1950s (Nowak and Pielowski 1964). By the 1980s, raccoon dogs had colonized over 1.4 million square kilometers of Europe (Nowak 1973; Nowak and Pielowski 1964; Kauhala and Saeki 2004a) and in many areas they became the most numerous carnivores (Jędrzejewska and Jędrzejewski 1998; Sidorovich et al. 2000; Kauhala et al. 2006). They colonized Białowieża Primeval Forest from the east and were first recorded in the early 1950s (Dehnel 1956; Bunevich and Dackevich 1985).

Invasive species often show great plasticity in adaptation to various environmental and climatic conditions (Ehrlich 1989; Sidorovich 1993; Kauhala 1996). Raccoon dogs occupy a wide range of habitats, from agricultural landscapes, to continuous forests (Jędrzejewska and Jędrzejewski 1998; Drygala et al. 2008a, b, c; Ansorge et al. 2009), and occur in a range of climatic conditions (Kauhala and Saeki 2004a, b). They are characterized by high reproductive capacity (Helle and Kauhala 1995; Kowalczyk et al. 2009) and high food habit plasticity (Kauhala 1996; Jędrzejewska and Jędrzejewski 1998). Raccoon dogs are omnivorous carnivores and their diet strongly varies between different locations (Kauhala et al. 1993; Jędrzejewska and Jędrzejewski 1998; Drygala et al. 2000; Sidorovich et al. 2000, 2008). They are also unique among canids as their overwintering strategy involves long periods of inactivity and winter lethargy (Asikainen et al. 2004; Mustonen et al. 2007. Kitao et al. 2009). However, little is known about their denning behavior. The use of burrows for reproduction and overwintering is reported (Goszczyński 1999; Kauhala et al. 2007; Drygala et al. 2008a, b, c; Kowalczyk et al. 2008), but the pattern of shelter use and its importance for the species remains unknown.

In this paper, we aimed to analyze patterns of shelter use by non-native raccoon dogs in a well-preserved natural forest that is inhabited by a rich community of animals, including large predators. We studied the influence of forest structure and climatic conditions on den-site selection. We hypothesized that during the most critical periods of the raccoon dog annual cycle, the pattern of shelter use will be adjusted to avoid predation and harsh weather conditions.
Study area

The study area $\left(130 \mathrm{~km}^{2}\right)$ was the center of the Polish section of the Białowieża Primeval Forest (BPF, $52^{\circ} 35^{\prime}-52^{\circ} 55^{\prime} \mathrm{N}$, $\left.23^{\circ} 30^{\prime}-24^{\circ} 00^{\prime} \mathrm{E}\right)$ - one of the best preserved temperate lowland forests in Europe. The study area included both the strictly protected Białowieża National Park (BNP) and the neighboring exploited forests. The latter are exploited by small clear-cuts with replantation or natural regeneration. The area is generally flat with gentle hills and shallow depressions. Coniferous forests (mainly pine Pinus silvestris and spruce Picea abies), cover 6\% of the area, mixed coniferous and deciduous forest (pine, spruce, oak Quercus robur with admixtures of birch Betula spp., and aspen Populus tremula) cover 39\%, rich deciduous forests (oak, hornbeam Carpinus betulus, lime Tilia cordata, and maple Acer platanoides) - 35\%, wet alder-ash forests (black alder Alnus glutinosa and ash Fraxinus excelsior) cover 13\%, and open habitats-7\% (Sokołowski 2006).

The BPF is unique among European forests due to its high tree and shrub diversity (26 and 55 species, respectively), which creates a multi-storey profile of tree stands. The strictly protected Białowieża National Park and the exploited forests differ in species composition and age structure, and in the amount of dead wood. The percentage of deciduous trees in BNP is $73 \%$ versus $46 \%$ in exploited forests. The average age of trees in BNP is 131 years and in exploited part of the forest 72 years (Jędrzejewska and Jędrzejewski 1998). The amount of fallen trees and dead wood in BNP is much higher (101$133 \mathrm{~m}^{3}$ per hectare), than in the exploited forests, where dead wood is very scarce $\left(0-1 \mathrm{~m}^{3} /\right.$ ha; Bobiec 2002).

The climate of BPF is transitional between Atlantic and continental types with clearly marked cold and warm seasons. The mean annual temperature in $1997-2002$ was $8.7^{\circ} \mathrm{C}$. The range of maximal and minimal temperatures recorded varied from $-33.4^{\circ} \mathrm{C}$ to $33.4^{\circ} \mathrm{C}$. The coldest month was January (mean daily temperature $-2.1^{\circ} \mathrm{C}$ ), and the warmest was July $\left(19.8^{\circ} \mathrm{C}\right)$. The number of days with a temperature below $0^{\circ} \mathrm{C}$ ranged from 50 to 89 (mean 73). Snow cover persisted for an average of 76 days per year (range 60-88) with a maximum recorded depth of $37 \mathrm{~cm}$. Mean annual precipitation during the study period was $500 \mathrm{~mm}$.

In BPF, the community of carnivores consists of 11 species, including two species of large predators: wolf $C$. lupus and lynx Lynx lynx. Raccoon dogs reached densities of 0.7 individuals per square kilometer (Jędrzejewska and Jędrzejewski 1998; Kowalczyk et al. 2003).

\section{Material and methods}

Radio-tracking was used to study the utilization of shelters by raccoon dogs. Animals were captured in the central part 
of the BPF (including both managed forest and Białowieża National Park) from September 1997 to March 2001, mainly in winter. Box and foot-snare traps were set near wintering dens (identified by snow-tracking) and fitted with alarm systems. Additionally, net and hand trapping was used (for details see Kowalczyk et al. 2008). In total, we captured 19 individuals (including five pairs), 11 by hand or net trapping, six in box traps, and two using foot-snare traps. The captured animals were immobilized with xylazine-ketamine (Kreeger 1997) and fitted with radiotransmitters (Advanced Telemetry System, USA).

Raccoon dogs were tracked 3-7 days a week, during both night and day. During the day raccoon dogs were localized more precisely from a distance of $20-50 \mathrm{~m}$, usually between 8.00 and $15.00 \mathrm{~h}$. When inactive, raccoon dogs were approached by observer to identify the type of resting site that they used. Inactivity of raccoon dogs was determined if the signal strength of the radio-transmitter stayed stable during at least a 2-min period of signal listening. This indicated that the transmitter on a raccoon dog had not changed its position in relation to the receiving antenna. Locations of pair mates resting together (both individuals observed together or localized within a maximum distance of $10 \mathrm{~m}$ ) were counted as one. When raccoon dogs were localized in a burrow or hollow tree, their position was estimated as precisely as possible with GPS receiver. Hollow trees were labeled to record re-use of the tree, and the species of the tree was identified. In total, we collected 1,086 daily locations of raccoon dogs in shelters.

Shelters used by raccoon dogs included day-time resting sites and breeding and wintering dens and they were divided into the following categories: (1) burrows: badger setts, or other dens, (2) hollow trees: cavities in hollow trunks of fallen or standing trees, (3) sedge tussocks or tall grasses, (4) thicket, (5) shelters under roots, trunks, or branches of fallen trees, (6) on the ground: not identified (shelters of type 4 or 5 , but not burrows or hollow treesprecise identification was not possible due to the risk of disturbance or raccoon dog escapes when approached), and (7) not hidden: on the ground, without cover.

We calculated the raccoon dogs' selection of tree species using Ivlev's electivity index, $D$ (modified by Jacobs 1974): $D=(r-p) /(r+p-2 p r)$, where: $r$ is the number of the given tree species that were used by raccoon dogs as fraction of all hollow trees used and $p$ is the fraction of a given tree species in the total number of trees with diameter at breast height $>40 \mathrm{~cm}$ (suitable for raccoon dogs), measured in 1998 on 48 sampling plots $0.5-1$ ha each (data from Protection and Management Plan of Białowieża National Park). $D$ ranges from -1 (the strongest negative selection) to +1 (the strongest positive selection), with 0 being random utilization.
To characterize shelter diversity in the annual cycle, The Levins' index of niche breadth $B$ (Levins 1968) was used: $B=1 / \Sigma p_{i}^{2}$, where $p_{i}$ was the fraction of each shelter type $i$. The calculation was done for seven shelter categories, so, B index varied from 1 (the narrowest niche) to 7 (the broadest niche possible).

The $\chi^{2}$ test was used to compare patterns of shelter use between the pristine old-growth forests of Białowieża National Park (BNP) and the exploited stands of BPF, G-test for homogeneity of percentages was used to compare patterns of resting behavior of pair mates in different biological periods of the annual life cycle, and a one-way analysis of variance (one-way ANOVA) was used to compare the selection of shelters in relations to ambient temperature. The analysis was computed using the SYSTAT 5.

\section{Results}

Types of shelters used by raccoon dogs

During the day, raccoon dogs utilized various types of shelters (Table 1). Most often they were found hidden in dense vegetation (sedges, thicket) or between different structures on the ground (branches, roots, and trunks of fallen trees; $59 \%$ of rest-days). They also often utilized burrows (usually main badger setts) and hollow trees ( $27 \%$ and $14 \%$ of days, respectively). Raccoon dogs were almost always hidden when resting ( $>99 \%$ of rest-days; Table 1).

We found statistically significant differences in shelter use by raccoon dogs between the pristine old-growth forests of Białowieża National Park and the exploited stands of $\mathrm{BPF}\left(\chi^{2}=501.46\right.$, d.f. $\left.=6, p<0.0001\right)$. In BNP, raccoon dogs utilized mainly hollow trees and the roots, trunks, and branches of fallen trees (38\% of locations) and sedge tussocks (37\%), whereas in the exploited forest they selected mainly burrows (43\%) and thickets (23\%) as shelters (Table 1).

We recorded 149 cases of hollow tree use by raccoon dogs (Table 2). Raccoon dogs used 30 fallen trees (on 131 days) and seven standing trees (on 18 days) of five species. Among all the species, lime trees were strongly selected by raccoon dogs for day-time shelters (Ivlev's electivity index $D=0.98$; Table 2). Of all hollow trees, $49 \%$ were used only once, $13 \%$-twice, and $38 \%$-three or more times (maximum of 19 times), mainly as wintering or breeding den.

Pattern of shelters use

Pattern of shelter use varied seasonally (Fig. 1). Burrows and hollow trees were utilized mainly in winter 
Table 1 Types of day-time shelters and the relative frequency of their utilization by radio-tracked raccoon dogs in the pristine old-growth forests of Białowieża National Park (ten individuals) and the exploited stands (nine individuals) in Białowieża Primeval Forest in 1997-2002

\begin{tabular}{|c|c|c|c|c|}
\hline \multirow[t]{2}{*}{ Shelter type } & \multirow[t]{2}{*}{$N$ localization } & \multicolumn{3}{|c|}{ Percentage of days spent in a given type of the shelter } \\
\hline & & $\begin{array}{l}\text { Whole forest } \\
N=1,086\end{array}$ & $\begin{array}{l}\text { Pristine forests (BNP) } \\
N=428\end{array}$ & $\begin{array}{l}\text { Exploited forests } \\
N=658\end{array}$ \\
\hline Burrows & 293 & 27.0 & 2.8 & 42.7 \\
\hline Main badger setts & 249 & 22.9 & & \\
\hline Other dens & 44 & 4.1 & & \\
\hline Hollow trees & 149 & 13.7 & 23.5 & 7.3 \\
\hline Fallen & 131 & 12.1 & & \\
\hline Standing & 18 & 1.6 & & \\
\hline On the ground & 635 & 58.5 & & \\
\hline Sedge tussocks or tall grasses & 179 & 16.5 & 37.0 & 3.2 \\
\hline Thicket & 162 & 14.9 & 3.0 & 22.6 \\
\hline Under roots, trunks, or branches of fallen trees & 97 & 8.9 & 14.3 & 5.5 \\
\hline Not identified & 197 & 18.2 & 17.3 & 18.7 \\
\hline Not hidden & 9 & 0.8 & 2.1 & 0 \\
\hline Total & 1,086 & 100.0 & 100.0 & 100.0 \\
\hline
\end{tabular}

(December-February), hollow trees during reproduction (May), and thickets during lactation (June-August). In those periods, the shelter diversity expressed by the niche breadth index (B) was lowest (Fig. 1). The highest diversity of shelters used was found in spring (MarchApril) and in autumn (September-November; Fig. 1).

The proportion of burrows and hollow trees used was inversely related to ambient temperature (burrows: $r^{2}=0.70$, $n=10$, temperature intervals, $p<0.0005$; hollow trees: $r^{2}=$ $0.46, n=10, p<0.0005$; and burrows and hollow trees together: $\left.r^{2}=0.87, n=10, p<0.0005\right)$. Burrows were selected at average ambient temperatures (mean $\pm \mathrm{SD}$ ) $1.5 \pm 5.6^{\circ}$ $\mathrm{C}$ (range, $-20.8 \pm 24.7^{\circ} \mathrm{C}$ ), hollow trees at $4.4 \pm 10.0^{\circ} \mathrm{C}$ (range, $-17.0 \pm 27.4^{\circ} \mathrm{C}$ ), and other shelters at $9.4 \pm 8.3^{\circ} \mathrm{C}$ (range, $-15.4 \pm 27.7^{\circ} \mathrm{C}$ ). The differences in temperatures between the three categories of shelters were statistically significant $(F=210.23$; d.f. $=1,1,084 ; p<0.0005)$. Based on the relationship, we proposed simple model explaining pattern of shelter use by raccoon dogs in relation to ambient temperature (Fig. 2).

Raccoon dogs used the mean of 1.4 dens $(\mathrm{SD}=0.7$, range $1-3, n=10$ raccoon $\operatorname{dog}$-winters) when wintering (periods of inactivity) and 1.1 dens $(\mathrm{SD}=0.3$, range $1-2$, $n=9$ raccoon dog-breeding seasons) when breeding (Fig. 3). Usually, the same den was selected from year to year for wintering (three out of four cases), and this differs for the breeding season (two out of three cases; Fig. 3). We did not observe use of wintering den by radio-collared raccoon dogs for breeding and inversely, use of breeding den for wintering. Of 19 breeding dens detected in 1997-

Table 2 Use of hollow trees for day-time shelters by raccoon dogs in BPF

\begin{tabular}{|c|c|c|c|c|c|}
\hline \multirow[t]{2}{*}{ Tree species } & \multicolumn{3}{|c|}{$\begin{array}{l}\text { Hollow trees used by raccoon } \\
\text { dogs }\end{array}$} & \multirow[t]{2}{*}{$\begin{array}{l}\text { Percentage share of the species in tree stands of } \\
\text { BPF }\end{array}$} & \multirow[t]{2}{*}{$\begin{array}{l}\text { Ivlev's electivity index } \\
D\end{array}$} \\
\hline & $\begin{array}{l}\text { Standing } \\
n=7\end{array}$ & $\begin{array}{l}\text { Fallen } \\
n=30\end{array}$ & $\begin{array}{l}\text { All } \\
n=37\end{array}$ & & \\
\hline Lime $T$. cordata & 1 & 125 & $126(84.5 \%)$ & 6.2 & 0.98 \\
\hline Ash Fraxinus excelsior & 14 & 1 & $15(10.1 \%)$ & 6.5 & 0.23 \\
\hline Aspen $P$. tremula & - & 4 & $4(2.7 \%)$ & 2.9 & -0.04 \\
\hline $\begin{array}{l}\text { Black alder Alnus } \\
\text { glutinosa }\end{array}$ & 2 & 1 & $3(2.0 \%)$ & 9.4 & -0.04 \\
\hline Oak $Q$. robur & 1 & - & $1(0.7 \%)$ & 14.0 & -0.92 \\
\hline Other species & - & - & $-(0 \%)$ & 61.0 & -1.00 \\
\hline Total & 18 & 131 & $149(100 \%)$ & 100.0 & \\
\hline
\end{tabular}


Fig. 1 Monthly pattern of shelter use by radio-collared raccoon dogs in Białowieża Primeval Forest in 1997-2002. Shelter niche breath (B) is given above the graph

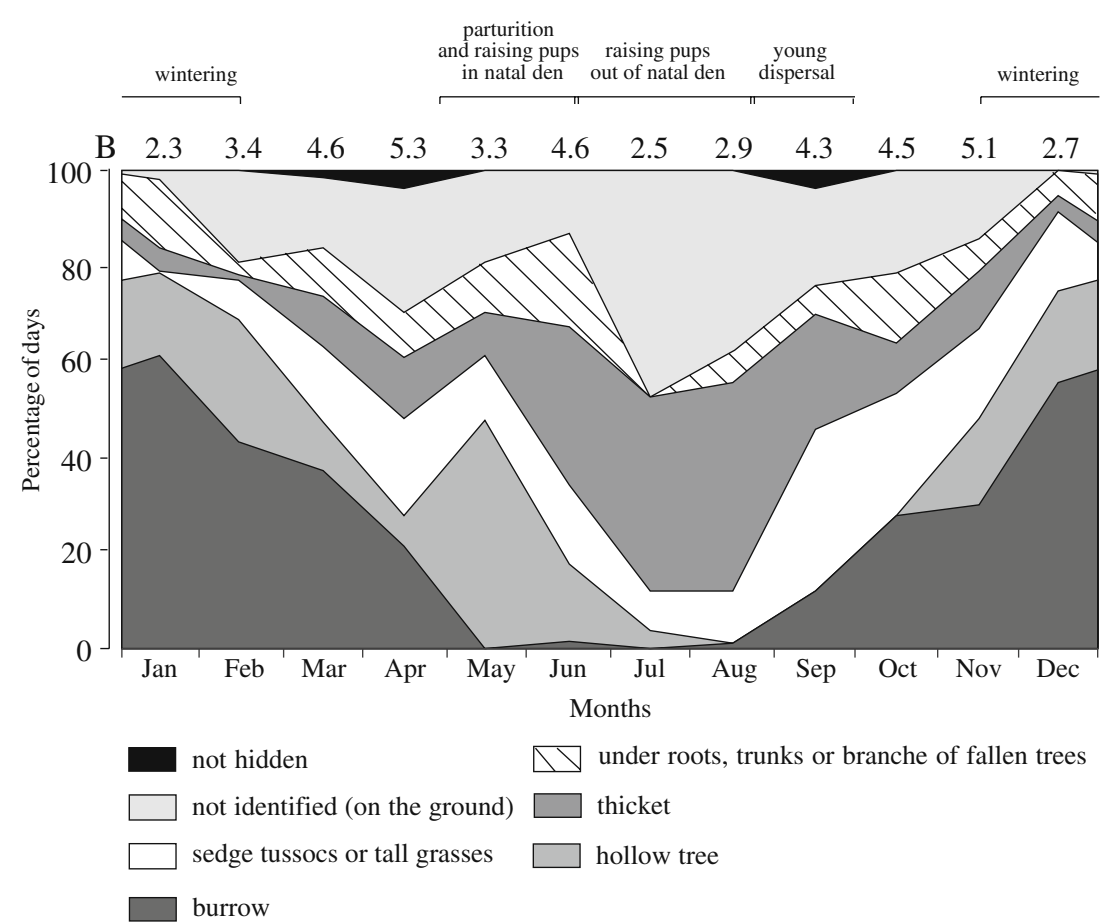

2008 (both collared and non-collared raccoon dogs), eight dens $(42 \%)$ were in active badger setts, seven (37\%) in hollow trees, and four (21\%) in other nests (one in thicket, one in sedge marsch, and two under roots of fallen trees). Seven out of eight cases of burrow use for reproduction

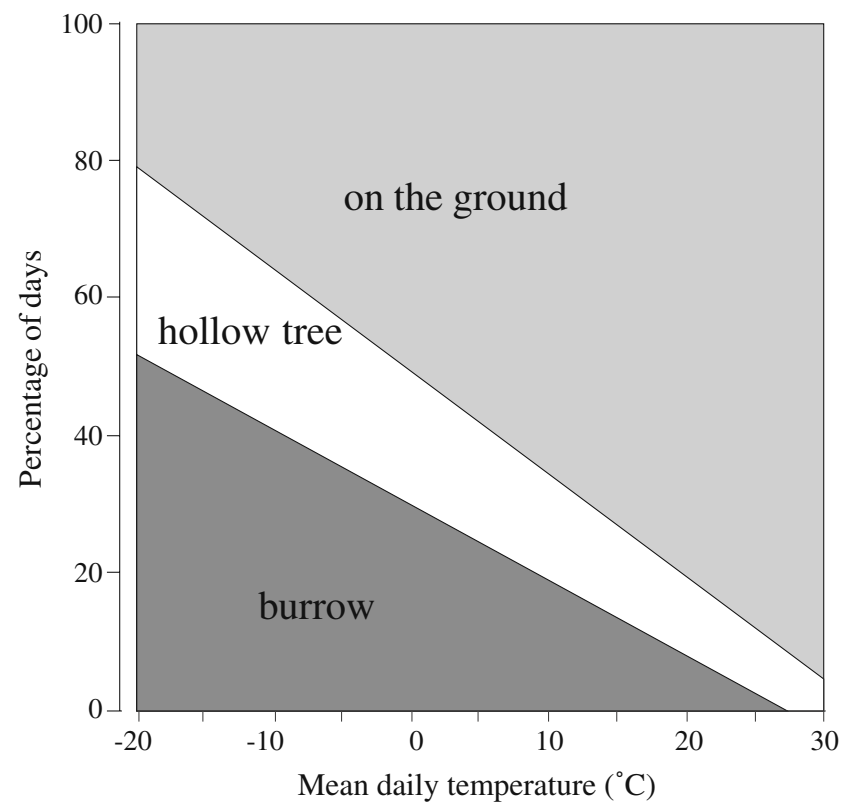

Fig. 2 Simple model explaining the relationship between the pattern of shelter use by raccoon dogs and mean daily temperature in Białowieża Primeval Forest in 1997-2002. Model based on correlations (see text) were recorded in the managed part of the Forest by noncollared individuals.

Social interactions at resting sites

Pair mates rested together on $83.9 \pm 7.0 \%$ of days a year, separately on $6.3 \pm 2.5 \%$, and one individual was resting while the second was active on $9.8 \pm 4.9 \%$ of days (Fig. 4). When resting separately, distance between pair mates was $561 \pm 439 \mathrm{~m}$, on average (range, 40-1,735 m). The resting behavior of pair mates significantly differed between breeding (May-August) and non-breeding period (September-April; G-test for homogeneity of percentages, $G=34.88$, d.f. $=2, p<0.001)$. During breeding period pair mates rested together on $64.1 \%$ of locations versus $95.3 \%$ in non-breeding period, separately on $11.4 \%$ of days (2.9\% in non-breeding period) and one individual was resting while the second was active on $24.5 \%$ of days (1.8\% in non-breeding period; Fig. 4).

\section{Discussion}

Raccoon dogs in Białowieża Primeval Forest showed a high degree of plasticity in their denning behavior, expressed by seasonal and spatial pattern of shelter use influenced by availability and cover quality of shelters. Shelters are essential for raccoon dog survival during the most crucial periods of their life cycle: reproductive period and winter. In such periods, raccoon dogs 
Fig. 3 Distribution of breeding and wintering dens $(n=20)$ in the home ranges of radiotracked raccoon dogs in Białowieża Primeval Forest

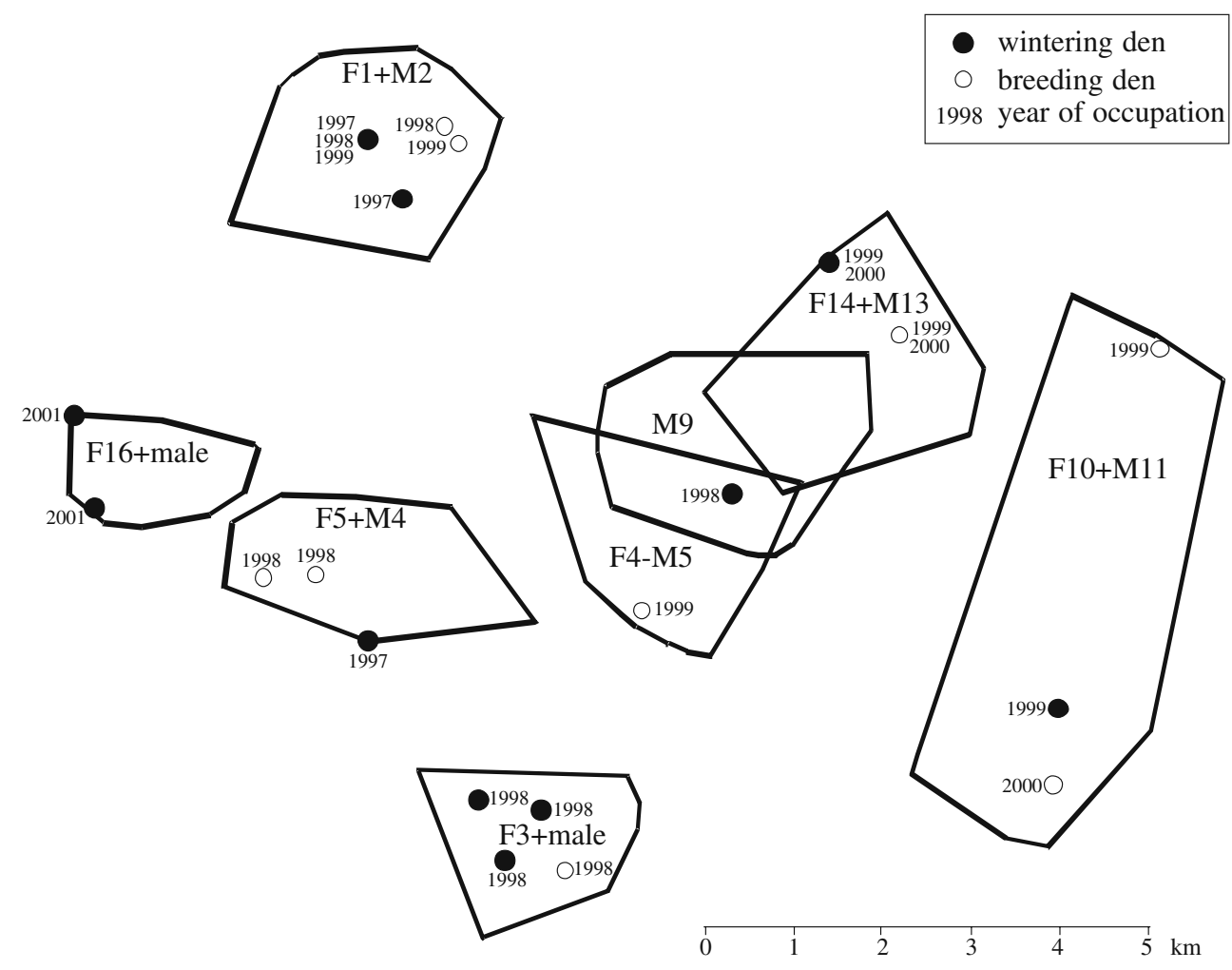

selected safer shelters, which was reflected by decreased width of shelter niche.

Thermal regulation and predator avoidance may underline den and resting site selection by animals (Lesmeister et al. 2008). In BPF, raccoon dog mortality is high and caused mainly by predation (Kowalczyk et al. 2009). It is especially high among raccoon dog pups, as nearly $60 \%$ of them die in first 3 months after parturition (Kowalczyk et al. 2009). In Finland only 20\% of juveniles reached 1 year of age (Helle and Kauhala 1993). In eight cases of badger sett use by raccoon dogs for reproduction, pups mortality due to badger predation was recorded in three cases
(Kowalczyk et al. 2009, unpublished, one to two pups of a litter killed simultaneously). The raccoon dogs response to increased mortality due to predation, was high compensatory reproduction (Kowalczyk et al. 2009), but also as shown by this study, selection of better shelters which allowed to avoid predation.

Predator pressure results in the evolution of defense mechanisms to escape from predation and promote survival (Schmidt and Amézquita 2001). Animals may change their behavior, e.g., movement pattern or resting site selection to reduce ability of predators to detect them (Brillhart and Kaufman 1991; Zalewski 1997a, b). Higher exposure to
Fig. 4 Seasonal variation of communal resting by raccoon dog pairs $(n=5)$ in Białowieża Primeval Forest

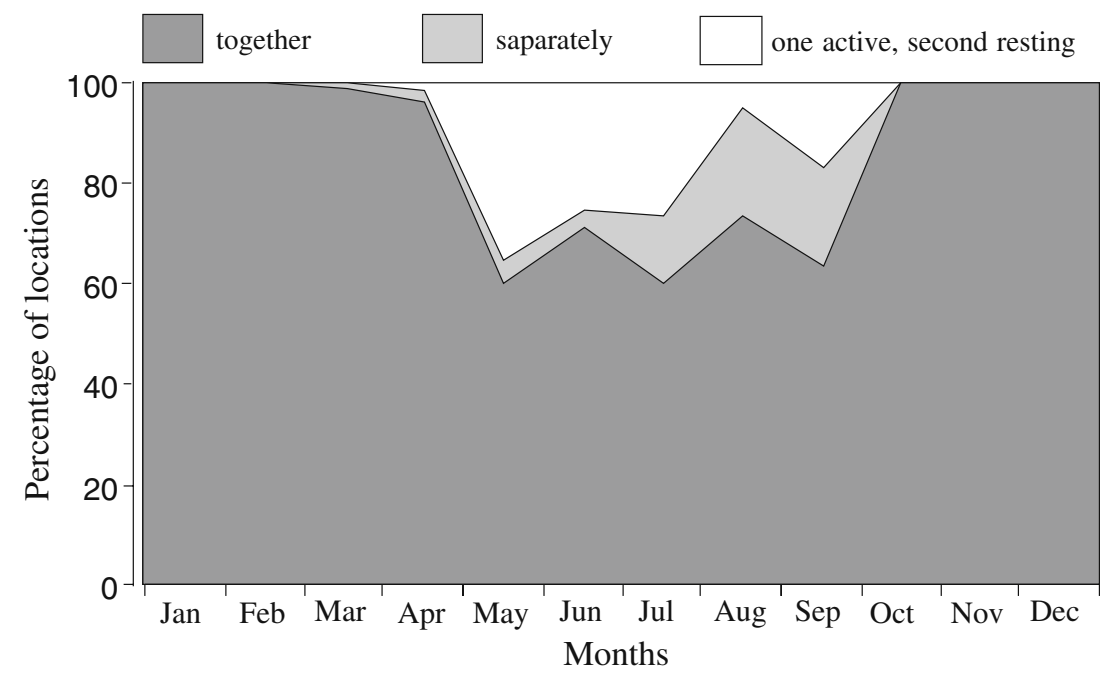


predation in winter might result from limited cover conditions and limited escape abilities of raccoon dogs due to snow cover and increased, by fat reserves, body mass. Most of avian and terrestrial predators use visuals signals to detect and chase their prey (Grant 1991; Kitchener 1991), so higher visibility increases the risk of predation. Dense vegetation may protect prey from their predators (Brown et al. 1988; Pietrek et al. 2009) and animals often select resting sites based primarily on increasing vegetative cover (Lesmeister et al. 2008). Because the high share of deciduous species in tree stands, visibility in the BPF increases from $33 \%$ in summer to $54 \%$ in late autumn-winter (Podgórski et al. 2008). Good cover conditions (selection of dense vegetation) were important for raccoon dogs after abandonment of their natal den to protect growing young. Similar behavior was also observed in Iberian lynx (Fernández et al. 2002). Higher visibility in winter forces raccoon dogs to select safer shelters, such as burrows and hollow trees.

Successful reproduction may be linked to the availability and quality of breeding den sites (Magoun and Copeland 1998; Fernandez and Palomares 2000). As shown by several studies, hollow trunks of trees are very important den sites for many species of carnivores (e.g., Fernandez and Palomares 2000; Zalewski 1997a). This was also the case in our study area, as most natal nests utilized by radiocollared raccoon dogs were found in fallen lime trees, and some raccoon dogs also spent winters in such shelters. Strong selection of raccoon dogs for this tree species results from its special features. In BPF, trunks of old limes reaching diameter up to $200 \mathrm{~cm}$ and, due to the very soft, decaying wood, are usually empty inside (Faliński 1977). This creates den-like spacious hollow (especially when fallen) utilized also by badgers (Kowalczyk et al. 2004). Hollow trees are probably safer for reproduction than badger setts as risk of predation in setts is higher due to high contact rate with the host species (badgers). We also recorded breeding of raccoon dogs in badger setts, but this type of shelter as the natal den was overrepresented as the probability of recording raccoon dog reproduction was high due to regular badger sett surveys (Kowalczyk et al. 2003, 2004). Burrows were selected for reproduction almost only in the managed part of the forest, where hollow trees were scarce.

The next factor shaping pattern of shelter use by raccoon dog is thermal stress during harsh winter conditions. It is indicated by increasing selection for burrows and hollow trees with decreasing ambient temperature. Winter conditions (low temperatures and snow cover) are limiting for raccoon dogs and may influence their growth and reproduction (Kauhala 1993; Helle and Kauhala 1995). Also winter mortality rate of juveniles $(77 \%)$ and adults $(50 \%)$ is higher than in other seasons (Helle and Kauhala 1993).
While the thick winter coat of raccoon dogs gives them good protection against the cold (Korhonen and Harri 1986, Korhonen et al. 1991), well-insulated shelters provide thermoregulation benefits and help save energy, especially during periods of inactivity and winter lethargy. Heat loss, and thus the energy costs in raccoon dogs, could be reduced by providing them with either a winter nest or a rest-shelf in the cage (Korhonen and Harri 1986). Consequently, raccoon dogs utilized the deep, complex badger setts and hollow trees.

Seasonally available food items constitute up to $50 \%$ of raccoon dog diet (Jędrzejewska and Jędrzejewski 1998), so to survive periods of food shortage raccoon dogs store fat reserves (Kauhala 1993, Kowalczyk R., unpublished data), settle into good shelters such as badger setts (Kauhala et al. 2007; Kowalczyk et al. 2008, this study) and undergo winter lethargy, at least in the northern part of the distribution area (Mustonen et al. 2007; Kitao et al. 2009). Raccoon dogs may compensate for seasonal limitation of food by carrion consumption (Jędrzejewska and Jędrzejewski 1998; Sidorovich et al. 2000; Selva et al. 2005), but this resource is limited and unpredictable in space and time. The use of carrion is additionally risky as much of it is derived from large predators (Selva et al. 2005), and scavenging from them increases the risk of mortality (Kowalczyk et al. 2009). Utilization of such resources leads to increased activity (Kistler et al. 2009), and together with limited cover, increases exposure to predation. A much better strategy is to collect fat reserves, decrease activity, and settle into safe shelter.

Burrows could be a limiting resource for raccoon dogs, as they rarely dig their own dens (Yudin 1977), and most often utilize burrows of other denning carnivores, such as badgers or foxes (Yudin 1977; Kowalczyk et al. 2000, 2008). In BPF, $85 \%$ of locations of raccoon dogs in burrows were in active badger setts. Use of dens excavated by other species may save time and energy; however, it carries the risk of predation from the burrow resident, as recorded also by us (Kowalczyk et al. 2008, 2009). Raccoon dogs in BPF usually used the same den for wintering in continuous years, which probably resulted from low availability of badger setts utilized most often by raccoon dogs for wintering (Kowalczyk et al. 2000, 2003, 2008). In Finland, 3.3 dens were used for hibernation every winter (Kauhala et al. 2007).

Habitat structure and cover conditions might influence the pattern of shelter use by animals (Zalewski 1997a, b; Huygens et al. 2001; Kowalczyk et al. 2006). The pristine state of the forest within the Białowieża National Park offers excellent cover for animals with its compound and mosaic vegetation structure and large amount of fallen timber. This was reflected by the pattern of shelter use by raccoon dogs, which utilized various den sites created by 
fallen trees and dense vegetation. In exploited tree stands, where the forest structure is simplified with little dead wood, raccoon dogs were forced to utilize the burrows of other denning carnivores-badgers and foxes-which might result in loss of offspring due to intra-guild predation (Kowalczyk et al. 2008, 2009). Influence of forest structure on the pattern of shelter use was previously found in badgers (Kowalczyk et al. 2006).

Observed variation in shelter use in relation to environmental conditions, shows also high plasticity of raccoon dogs, typical for invasive species (Ehrlich 1989, Kauhala 1996). High adaptability to both natural and disturbed areas may be one of the factors underlying successful range expansion of raccoon dogs in Europe (Nowak 1973; Kauhala and Saeki 2004a, b; Drygala et al. 2008b).

Communal resting by male and female indicates strong monogamy in the species (Kleiman 1977). Raccoon dogs exhibit such monogamy, moving and resting together or very close to each other for most of the year (Kauhala and Helle 1994; Kauhala and Holmala 2006; Drygala et al. 2008c, this study). As reported by Kauhala and Holmala (2006), members of the pair spent $84 \%$ of time together in winter and $67 \%$ in summer. Decrease of joint resting during the breeding period results from time allocation of male and female to pup rearing and food collection (Kauhala et al. 1998, Drygala et al. 2008b). Both parents participate in care for pups, and both parents, or one of the individuals, always guard pups during first 6 weeks after parturition while the other forages (Drygala et al. 2008b). Very close relationships between pair mates, manifested by joint resting, may lead however to disease (such us sarcoptic mange or rabies) transmission or simultaneous mortality due to predation (Kowalczyk et al. 2009).

Based on our findings, we conclude that hiding behavior and plasticity in utilization of various shelters by raccoon dogs in Białowieża Primeval Forest is a response to predator pressure and to climatic severity modified by habitat conditions. Shelters that provided refuge were selected in the most crucial periods of their life cycle, allowing raccoon dogs to protect their infant young during the breeding season and survive winters-periods of food shortage and lower cover accessibility.

Investigation of shelter use by invasive raccoon dogs in different environmental condition, both with and without large predators, is essential for understanding high plasticity of invasive species and their adaptability to various environmental conditions, which probably underlie their successful expansions.

Acknowledgments This project was funded by the Polish State Committee for Scientific Research (grant of KBN 6 P04C 057 12) and the Polish Academy of Sciences, Mammal Research Institute.
Permission to trapping raccoon dogs was granted by the Ministry of Environment and director of the Białowieża National Park. We thank E. Bujko and numerous students for their help in radiotracking and observations of raccoon dogs. We also thank Dr. M. Hayward for useful comments to the manuscript and English revision.

Open Access This article is distributed under the terms of the Creative Commons Attribution Noncommercial License which permits any noncommercial use, distribution, and reproduction in any medium, provided the original author(s) and source are credited.

\section{References}

Ansorge H, Ranyuk M, Kauhala K, Kowalczyk R, Stier N (2009) Raccoon dog Nyctereutes procyonoides populations in the area of origin and in colonised regions - the epigenetic variability of an immigrant. Ann Zool Fenn 46:51-62

Asikainen J, Mustonen AM, Hyvärinen H, Nieminen P (2004) Seasonal physiology of the wild raccoon dog (Nyctereutes procyonoides). Zool Sci 21:385-391

Bobiec A (2002) Living stands and dead wood in the Bialowieża forest: suggestion for restoration management. For Ecol Manage 165:125-140

Brillhart DB, Kaufman DW (1991) Influence of illumination and surface structure on space use by Prairie Deer Mice (Peromyscus maniculatus bairdii). J Mamm 72:764-768

Brown JS, Kotler BR, Smith RJ, Wirtz WO (1988) The effects of owl predation on the foraging behavior of heteromyid rodents. Oecologia 76:408-415

Bunevich AN, Dackevich VA (1985) Spatial distribution and food of the raccoon dog in Białowieża Forest. Zapovedniki Belorussii 9:114-120 [in Russian]

Buskirk SW (1984) Seasonal use of resting sites by marten in SouthCentral Alaska. J Wildl Manage 48:950-953

Cantú-Salazar L, Hidalgo-Mihart MG, López-González CA, González-Romero A (2009) Dry season den use by Pygmy Spotted Skunk (Spilogale pygmaea) in a tropical deciduous forest of Mexico. Biotropica 41:347-353

Dehnel A (1956) New species of mammal in Polish fauna Nyctereutes procynoides (Gray). Chrońmy Przyrodę Ojczystą 12(6):17-21 [in Polish]

Drygala F, Mix HM, Stier N, Roth M (2000) Preliminary findings from ecological studies of the raccoon dog (Nyctereutes procyonoides) in north-eastern Germany. Zeitschrift für Ökologie und Naturschutz 9:147-152

Drygala F, Stier N, Zoller H, Mix H, Roth M (2008a) Habitat use of the raccoon dog (Nyctereutes procyonoides) in north-eastern Germany. Mamm Biol 73:371-378

Drygala F, Zoller H, Stier N, Mix H, Roth M (2008b) Ranging and parental care of the raccoon dog Nyctereutes procyonoides during pup rearing. Acta Theriol 53:111-119

Drygala F, Stier N, Zoller H, Mix H, Bögelsack K, Roth M (2008c) Spatial organization and intra-specific relationship of the raccoon dog Nyctereutes procyonoides in Central Europe. Wildlife Biology 14:457-466

Ehrlich PR (1989) Attributes of invaders and the invading processes: vertebrates. In: Drake JA, Mooney HA, di Castri F, Groves RH, Kruger FJ, Rejmánek M, Williamson M (eds) Biological invasions: a global perpective SCOPE 37. Wiley, New York, pp 315-328 
Faliński JB (1977) Białowieża Primeval Forest. Phytocoenosis 6:133148

Fernandez N, Palomares F (2000) The selection of breeding dens by the endangered Iberian lynx (Lynx pardinus): implications for its conservation. Biol Conserv 94:51-61

Fernández N, Palomares F, Delibes M (2002) The use of breeding dens and kitten development in the Iberian lynx (Lynx pardinus). J Zool 258:1-5

Friebe A, Swenson JE, Sandegren F (2001) Denning chronology of female brown bears in Central Sweden. Ursus 12:37-45

Goszczyński J (1999) Fox, raccoon dog and badger densities in north eastern Poland. Acta Theriol 44:413-420

Goszczyński J, Misiorowska M, Juszko S (2008) Changes in the density and spatial distribution of red fox dens and cub numbers in central Poland following rabies vaccination. Acta Theriol 53:121-127

Grant JDA (1991) Prey location by 12 Australian Long-Eared Bats, Nyctophilus-Gouldi and N-Geoffroyi. Aust J Zool 39:45-56

Helle E, Kauhala K (1993) Age structure, mortality, and sex ratio of the raccoon dog in Finland. J Mammal 74:936-942

Helle E, Kauhala K (1995) Reproduction in the raccoon dog in Finland. J Mammal 76:1036-1046

Herr J, Schley L, Engel E, Roper TJ (2010) Den preferences and denning behaviour in urban stone martens (Martes foina) Mamm Biol. 75:138-145

Huygens O, Goto M, Izumiyama S, Hayashi H, Yoshida T (2001) Denning ecology of two populations of Asiatic black bears in Nagano prefecture, Japan. Mammalia 65:417-428

Jacobs J (1974) Quantitative measurement of food selection: a modification of the forage ratio and Ivlev's electivity index. Oecologia 14:413-417

Jędrzejewska B, Jędrzejewski W (1998) Predation in vertebrate communities: the Białowieża Primeval Forest as a case study. Ecological Studies 135. Springer, Berlin, p 450

Jędrzejewski W, Schmidt K, Theuerkauf J, Jędrzejewska B, Okarma H (2001) Daily movements and terriotory use by radio-collared wolves (Canis lupus) in Białowieża Primeval Forest in Poland. Can J Zool 79:1993-2004

Kauhala K (1993) Growth, size, and fat reserves of the raccoon dog in Finland. Acta Theriol 38:139-150

Kauhala K (1996) Introduced carnivores in Europe with special reference to central and northern Europe. Wildl Biol 2:197204

Kauhala K, Helle E (1994) Home ranges and monogamy of the raccoon dog in southern Finland. Suomen Riista 40:32-41

Kauhala K, Holmala K (2006) Contact rate and risk of rabies spread between medium-sized carnivores in southeast Finland. Ann Zool Fenn 43:348-357

Kauhala K, Saeki M (2004a) Raccoon dogs. In: Sillero-Zubiri C, Hoffmann M, Macdonald DW (eds) Canids: foxes, wolves, jackals and dogs. Status survey and conservation action plan. IUCN/SSC Canid Specialist Group, Gland, pp 136-142

Kauhala K, Saeki M (2004b) Raccoon dogs. Finnish and Japanese raccoon dogs - on the road to speciation? In: Macdonald DW, Sillero-Zubiri C (eds) Biology and conservation of wild canids. Oxford University Press, Oxford, pp 217-226

Kauhala K, Helle E, Pietila H (1998) Time allocation of male and female raccoon dogs to pup rearing at the den. Acta Theriol 43:301-310

Kauhala K, Holmala K, Schregel J (2007) Seasonal activity patterns and movements of the raccoon dog, a vector of diseases and parasites, in southern Finland. Mammalian Biology 72:342-353

Kauhala K, Kaunisto M, Helle E (1993) Diet of the Raccoon dog, Nyctereutes procyonoides, in Finland. Z Säugetierk 58:129136
Kauhala K, Holmala K, Lammers W, Schregel J (2006) Home ranges and densities of medium-sized carnivores in south-east Finland, with special references to rabies spread. Acta Theriol 51:1-13

Kistler C, Hegglin D, Würbel H, König B (2009) Feeding enrichment in an opportunistic carnivore: the red fox. Appl Anim Behav Sci 116:260-265

Kitao N, Fukui D, Hashimoto M, Osborne PG (2009) Overwintering strategy of wild free-ranging and enclosure-housed Japanese raccoon dogs (Nyctereutes procyonoides albus). Int J Biometeor 53:159-165

Kitchener A (1991) The natural history of the wild cats. Christopher Helm, A. and C. Black, London

Kleiman DG (1977) Monogamy in mammals. Q Rev Biol 52:39-69

Korhonen H, Harri M (1986) Heat loss of farmed raccoon dogs and blue foxes as evaluated by infrared thermography and body cooling. Comp Biochem Physiol A 84:361-364

Korhonen H, Mononen J, Harri M (1991) Evolutionary comparison of energy economy between finnish and Japanese raccoon dogs. Comp Biochem Physiol A 100:293-295

Kowalczyk R, Bunevich AN, Jędrzejewska B (2000) Badger density and distribution of setts in Białowieża Primeval Forest (Poland and Belarus) compared to other Eurasian populations. Acta Theriol 45:395-40

Kowalczyk R, Zalewski A, Jędrzejewska B (2004) Seasonal and spatial pattern of shelter use by badgers Meles meles in Białowieża Primeval Forest (Poland). Acta Theriol 49:75-92

Kowalczyk R, Zalewski A, Jędrzejewska B (2006) Daily movements and territory use by badgers Meles meles in Białowieża Primeval Forest, Poland. Wildlife Biol 12:385-391

Kowalczyk R, Zalewski A, Jędrzejewska B, Jędrzejewski W (2003) Spatial organization and demography of badgers Meles meles in Białowieża Forest (Poland) and the influence of earthworms on badger densities in Europe. C J Zool 81:74-87

Kowalczyk R, Jędrzejewska B, Zalewski A, Jędrzejewski W (2008) Facilitative interactions between the Eurasian badger (Meles meles), the red fox (Vulpes vulpes), and the invasive raccoon dog (Nyctereutes procyonoides) in Białowieża Primeval Forest, Poland. C J Zool 86:1389-1396

Kowalczyk R, Zalewski A, Jędrzejewska B, Ansorge H, Bunevich AN (2009) Reproduction and mortality of invasive raccoon dogs Nyctereutes procyonoides in Białowieża Primeval Forest (Poland). Ann Zool Fenn 46:291-301

Kreeger TJ (1997) Handbook of wildlife chemical immobilization. Wildlife Pharmaceuticals Inc., Fort Collins

Lesmeister DB, Gompper ME, Millspaugh JJ (2008) Summer resting and den site selection by eastern spotted skunks (Spilogale putorius) in Arkansas. J Mamm 89:1512-1520

Levins R (1968) Evolution of changing environments. Princeton University Press, Princeton

Magoun AJ, Copeland JP (1998) Characteristics of wolverine reproductive den sites. J Wildl Manage 62:1313-1320

McLoughlin PD, Cluff HD, Messier F (2002) Denning ecology of barren-ground Grizzly bears in the central Arctic. J Mamm 83:188-198

Mustonen AM, Asikainen J, Kauhala K, Paakkonen T, Nieminen P (2007) Seasonal rhythms of body temperature in the free-ranging raccoon dog (Nyctereutes procyonoides) with special emphasis on winter sleep. Chronobiol Int 24:1095-1107

Nowak E (1973) Ansiedlung und Ausbreitung des Marderhundes (Nyctereutes procynoides Gray) in Europa. Beiträge zur Jagdund Wildforschung 8:351-384

Nowak E, Pielowski Z (1964) Die Verbreitung des Marderhundes in Polen im Zusammenhang mit seiner Einbürgerung und Ausbreitung in Europa. Acta Theriol 9:81-110 
Pietrek AG, Walker RS, Novaro AJ (2009) Susceptibility of lizards to predation under two levels of vegetative cover. J Arid Environ 73:574-577

Podgórski T, Schmidt K, Kowalczyk R, Gulczyńska A (2008) Microhabitat selection by Eurasian lynx and its implications for species conservation. Acta Theriol 53:97-110

Reichman OJ, Smith S (1990) Burrows and burrowing behavior by mammals. In: Genoways HH (ed) Current mammalogy. Plenum, New York, pp 197-244

Schmidt BR, Amézquita A (2001) Predator-induced behavioural responses: tadpole of the neotropical frog Phyllomedusa tarsius do not respond to all predators. Herpetol J 11:9-15

Selva N, Jędrzejewska B, Jędrzejewski W, Wajrak A (2005) Factors affecting carcass use by a guild of scavengers in European temperate woodland. Can J Zool 83:1590-1601

Sidorovich VE (1993) Reproductive plasticity of the American mink Mustela vison in Belarus. Acta Theriol 38:175-183

Sidorovich VE, Polozov AG, Lauzhel GO, Krasko DA (2000) Dietary overlap among generalist carnivores in relation to the impact of the introduced raccoon dog Nyctereutes procyonoides on native predators in northern Belarus. Z Säugetierk 65:271-285

Sidorovich VE, Solovej IA, Sidorovich AA, Dyman AA (2008) Seasonal and annual variation in the diet of the raccoon dog Nyctereutes procyonoides in northern Belarus: the role of habitat type and family group. Acta Theriol 53:27-38

Sokołowski AW (2006) Forests of north-eastern Poland. Centrum Informacyjne lasów Państwowych, Warszawa [in Polish]

Theuerkauf J, Rouys S, Jędrzejewski W (2003) Selection of den, rendezvous, and resting sites by wolves in the Białowieża Forest, Poland. Can J Zool 81:163-167

Yudin VG (1977) Enotovidnaja sobaka Primoria i Priamuria. Izd Nauka, Moscow

Zalewski A (1997a) Factors affecting selection of resting site type by pine marten in primeval deciduous forests (Białowieża National Park, Poland). Acta Theriol 42:271-28

Zalewski A (1997b) Patterns of resting site use by pine marten Martes martes in Bialowieża National Park (Poland). Acta Theriol 42:153-168 